\title{
Land conflicts and the livelihood of Pastoral Maasai Women in Kilosa district of Morogoro, Tanzania'
}

\author{
Lucy Willy Massoi \\ Department of Conflict and Development Studies, Ghent University
}

\begin{abstract}
This summary of my PhD thesis analyses conflicts around land in relation to pastoral Maasai women livelihoods in Tanzania. Issues of pastoralism and land use conflicts in Tanzania are well documented in literature. However, a gendered analysis of conflicts around land in relation to land reforms (changes in the use and ownership of, and access to land and land resources), prolonged climate variability and change, and food insecurity, hardly exists in the literature. Of particular concern is the rudimentary analysis of these conflicts as it relates to pastoral Maasai women, the primary and secondary users of land in pastoral livelihoods. Data analysed in this report were collected in Kilosa district, located in Morogoro, Tanzania, one of the renowned hotspots for pastoral-farmer conflicts in Tanzania. Within Kilosa, data were collect in pastoral Maasai settlements [villages] of Twatwatwa, Kiduhi, Ngaiti, and Mabwegere, and pastoral Maasai women were central focus. Through ethnographic research methods namely focus group discussions, interviews, and participant observations, I have found that vulnerabilities to conflicts around land are gender differentiated, and that pastoral Maasai women experience climate change, food insecurity, and land reforms differently from men. An overall conclusion in this report is that, conflicts around land in Kilosa are intricate in nature and cannot be analysed from a single narrative, and pastoral Maasai women by virtue of their specific gender roles and the gender relations are hit hard. I therefore argue that, (I) for secure land reforms, the political, economic, and social structures through which land access is mediated must also be reformed; (2) there should be a holistic conflict mitigation approach and strategies in resolving conflict around land in Kilosa. The approaches should focus at engaging pastoralists and pastoralist women in particular, and their institutions and making them an integral part of the solutions. (3) Decisions dealing with climate change mitigation strategies such as the Kilosa eviction of 2009 should also involve pastoralist women whose livelihood depends directly and/or indirectly on climate sensitive resources; (4) the introduction of forage crops production [such as grasses and legumes] in Kilosa is imperative. This will assist in increasing pasture production, which eventually will boost livestock production [livestock, the main preferred food source among the pastoral Maasai]. Equally, availability
\end{abstract}


of forage crops within pastoralists reach reduces unplanned herd mobility, and at the same time lessens challenges that pastoralist women face in their responsibilities as default food managers.

Key words: Bantu languages, Ubangian languages, contact langues, documentations, reconstructions, classifications

\section{Introduction}

This research analyses conflicts around land in relation to pastoral Maasai women livelihoods in Tanzania. It specifically explores various types of land conflicts, those related to climate change, food insecurity and land reforms, and considers the implication for pastoral women as they attempt to carry out their specific gender roles in pastoral society. Gender is broadly conceptualized across literature (Hughes and Hughes, 200I; Nelson, 2008). This research draws from Butler (I990) by viewing gender as a culturally and socially constructed relationship between men and women, and geographically and historically specific, and so it will inevitably change over time and through space. This research stems from the argument that issues of land use conflicts and pastoralism in Tanzania are well documented in literature (Shao, 2008; Benjaminsen et al., 2009; King, 20I3; Misafi, 20I4). However, a gendered analysis of conflicts around land in relation to land reforms (changes in the use and ownership of, and access to land and land resources), prolonged climate variability and change, and food insecurity, hardly exists in the literature. Of particular concern is the rudimentary analysis of these conflicts as it relates to pastoral Maasai women, the primary and secondary users of land in pastoral livelihoods (Flintan, 2008).

Analysis of conflicts around land in relation to land reforms, climate change, food (in)security and gender draw us into the following on-going debates. The first body of literature which centres on land, conflicts and gender indicates that, on the one hand women and men experience conflicts differently, depending on the specific socio-cultural induced gender roles and relations prevailing in their society (Mkutu, 2008; Young and Sing'Oei, 20II). On the other hand, there is also literature which suggests that conflicts affect the entire community irrespective of gender [Maganga et al., 2007]. I have argued that, when conflicts occur, women are affected differently from men because of certain gender specific roles they play in their societies. The second body of literature which centres on land reforms and gender is governed by two opposing academic arguments: on the one hand, individualised land rights are more effective and desirable in promoting tenure security and efficient use of land (Obeng-Odoom, 20I2). Land individualization stimulates market-oriented land transactions, and provides the landless and multiple social groups [including women] with wider equal opportunities to participate in a more secured manner (De Soto, 2000; Pedersen and Haule, 2013). On the other hand, advocates of communal land rights believe the traditional forms of tenure as the most effective way to ensure secure tenure and promote gender equality in accessing land and land resources (Obeng-Odoom, 20I2). I argue that reforming statutory land laws and institutions governing land alone, is not enough to guarantee tenure security among women. The third body of literature on conflicts focuses on climate change, land conflicts 
and gender, where four theoretical standpoints exist. On one hand, scholars claim that there is a direct, linear, causal linkage between change in climate, scarcity, and violent conflict (Diamond, 2005; Moon, 2007). On the other hand, literature also emphasises that there are indirect linkages between climate change and conflict, and thus climate is just a threat multiplier of existing vulnerabilities (Barnett and Adger, 2007; Hoste and Vlassenroot, 2009. There is also literature claiming that the causal link between climate change and conflicts is political (Meier et al 2007; Morrissey, 2009; Levine et al., 20I4). Regardless of their causal relationship, Omolo and Ashber are of the view that there are disproportionate vulnerabilities to climate change effects due to gender (Omolo, 2010; Ashber, 2012). Anyhow, I argue that climate change is just one among several factors that aggravate conflict, and ultimately exacerbate the plight of women.

The fourth body of literature centers on food security, where conflicts and gender are concerned, whereby three arguments are embedded in the literature. Firstly, conflicts are viewed as factors in instigating food shortage by affecting local food systems (Messer and Cohen, 2006; Vlassenroot et al., 2006). Thirdly, the consequent food insecurity can be an unintended by-product of conflict but can also be a deliberate strategy of actors in conflict (Devereux, 2000). From a gendered perspective, literature indicates that, unlike men, women as food managers are highly affected by food insecurity induced conflict (Misselhorn, 2005; Simmons, 2013). This may be simply seen as being due to the fact that women's traditional role is to ensure that everybody within a household is fed (Flintan, 2008; Karl, 2009). However, very scanty information is documented to ascertain the link between food (in)security and conflicts from a gendered perspective. This work advances that conflicts and food insecurity are intricately linked, and women as default food managers shoulder the heaviest burden.

\section{Methodology}

Data analysed in this research were collected in Kilosa district, located in Morogoro, Tanzania. Within Kilosa, I used purposive and snowballing sampling methods to select the four pastoral Maasai settlements (Mabwegere, Ngaiti, Parakuyo, and Kiduhi) and 6o respondents where land disputes have been prevalent (Benjaminsen et al., 2009; Riesman et al., 20I3; URT, 20I0). This made it possible to have pastoral Maasai women as the central focus of this ethnographic-inspired research (Redding-Jones, 2005: 72). This was done at three levels: at the central level, I was able to hold an interview with the Inspector General of Police (IGP) ${ }^{2}$ and the Permanent Secretary-Ministry of Lands, Housing and Human settlement ${ }^{3}$. At the regional level, it was possible to engage the Regional Police Commander for the Morogoro Region and the Officer Commanding the Criminal Investigation Department for the region. In Kilosa district interviews were obtained with: the District Administrative Secretary, the District Executive Director, Heads of Departments [Community Development and Social Welfare and Planning], District Agricultural and

2 In October, 2010 in Dar es Salaam, Tanzania

3 In October 2010 in Kampala, Uganda during the International conference of land for East Africa, which he also attended. 
Livestock Officers, and the District Land Officer. Amongst the police it was possible to speak with the Officer Commanding the District, the Officer Commanding the Criminal Investigation for the District, and the Officer Commanding the Station. The total number of respondents in this category was 20 government officials. Maasai elders also consented to be interviewed, and one elder in each pastoral settlement was selected, making a total of 4 elders, and I Maasai spiritual leader 'Olegwenan'. As a patriarchal society, it was important to include their views on the subject under study. 6 in-depth interviews were held with Maasai women. The discussion of personal matters such as rape during conflict and relationship matters necessitated a more private setting than focus groups. Generally, these interviews were unstructured and lasted between I to 3 hours. In addition to in-depth interviews discussed above, telephone interviews were carried out with 3 village chairpersons, 2 Maasai elders and 4 Maasai pastoralist women. Data collected from Kilosa and theoretical arguments were combined with a Political Economy Approach [PEA] and a Sustainable Livelihood Approach [SLA] to analyse land conflicts and the livelihood of pastoral Maasai women in Kilosa. In the following subheadings, results from the research are summarized and presented based on the key research questions.

\section{Land reforms, conflicts and pastoral Maasai women}

The first research question focused on land reforms in Tanzania, and the manner in which they have affected the livelihood position of the pastoralist women in Kilosa district. Results indicate that statutory laws and customary rule among the pastoral Maasai contradict when it comes to women's land rights. The customary rule of the pastoral Maasai overtly denies the right of women to property ownership (including land) and inheritance, because they themselves are property of men. Thus pastoral women continue to fall into a legal black hole due to customs and traditions that restrict their access, contradicting the presumption that market oriented reforms are the most important channels for promoting and ensuring land acquisition for women. Thus for most pastoral Maasai women, the communal land tenure system is their only route to benefit from land, and this through secondary rights of access through relationships with their husbands, fathers and sons. However, reforms had the effect of opening up the communal land of the pastoral Maasai to a multitude of forces, which for the most part actually diminished the secondary right of access women enjoyed under the communal system. With land privatization the emphasis on land markets, individual land holding, and investment interests has created two main problems, with grave impacts on pastoral women in particular.

Land reforms have opened up the traditionally held lands of Maasai to state acquisitions (appropriation) and alienations. Ironically, they have also created tenure contradictions; whereby the same laws that allow local communities [pastoralists in this case] to hold land under the customary system are also used to push them away for investors. A typical case is that of Mkata ranch, which involves the state, investors and pastoralists of the Ngaiti-sub village in Kilosa district. Here tenure contradiction is at its worst, licensing the exclusion of pastoralists, especially pastoral women. With privatization, women 
are losing some traditional secondary rights and indirect benefits traditionally enjoyed under the communal system. This is compounded by a lack of negotiating power in the decision-making bodies [both within the local government level and community], and within their families [as they own nothing for themselves]. On a similar note, large-scale commercial farming is increasingly subjecting women to an insecure and uncertain future, arguments also shared by Flintan (201I) and Kipuri and Ridgewell (2008).

Worsening the situation is the weakening of customary institutions [clans, families and marriage] by privatization, which initially guaranteed women's access. Moreover, land enclosures by investors have also increased daily domestic workloads on women related to fetching water in dry season. This result depicts one of the dangers of land reforms on women in eroding customary rights and overburdening them, as concurred by Joekes and Pointing (I99I). This supports the skeptical position that the communitarian schools have against the individualization of land rights in offering wider land access opportunities for women (Deere and Leon, 2003). A shift in livelihood strategy is an important aspect of large scale commercial farming, land privatization and land grabbing as male pastoralists either move to a sedentary life or join the rural-urban migration trend in the search for an alternative economic niche. The amalgamations of these changes have particularly affected pastoral women, by creating land insecurity, and creating a class system among the pastoral communities. Existing expectations of gender roles and systems work together with these pressures to place intolerable workloads on women as they attempt to meet their responsibilities and needs as is also observed by Fratkin and Roth (2006). The emergence of classes among pastoralists is an interesting dynamic in Kilosa. Increasingly, economic differentiation is evident among the pastoralists, as the rich and powerful categories of the Maasai are increasingly grabbing communal land for individual use. In this situation of haves and the have-nots, certain women already disadvantaged by their gender are then further disadvantaged in terms of their class.

While findings depict that women are victims of these changes, a few cases were evident of women able to break the edge of customs and traditions blocking their capacity to benefit from the reformed land tenure system. Simply put, some women are increasingly taking a bold stance towards land access, by defying both statutory and customary practices that deny their access to land. This includes creation of new routes of land access, and in some cases new rights. However, these cases are few and for the most part do not represent the situation for the majority of pastoral women in Kilosa who are increasingly subjected to more vulnerable situations including engaging into prostitution in order to survive. Thus, land reforms in Tanzania have generally not been in favour of pastoralism, or pastoral women in particular. Pastoral women are disadvantaged as pastoralists and also as women. As women they endure, firstly, persisting discriminatory social norms and practices that restrict their ability to benefit from statutory rights. Secondly, existing overlapping, contradictions and discriminations in the existing statutory land laws, predominantly around marriage, inheritance and control over land also do not work in favour of these women. Thirdly, women lack the ability to seek redress or exercise agency. As noted, very few women are able to take a bold stance against existing discriminatory 
practices to demand that their rights be enforced within their customary and formal institutions. Few are like Mama Anna Oloishuro, and few can seek redress or even demand enforcement of their rights within their customary institutions and statutory bodies (village authorities). Fourthly, a complex interaction of markets, social norms, and land laws that mediates women's rights of access and use also constrains women from benefiting from these reforms. I argue that reforming statutory land institutions without first reforming the customary land holding first is a fault in reforms and a double blow to pastoral women.

Lastly, regardless of the good intentions of land reforms to mitigate land conflicts, fifteen years later, conflicts continue and are even more frequent and intense for a variety of reasons. Contradictory laws have led to conflict between the state, or investors and the people or communities the state is supposed to protect. Women as is noted, have often been rendered particularly insecure as a result.

\section{Land conflicts in Kilosa and pastoral women}

The second research question aimed at exploring land use conflicts in Kilosa and how they impact on women and existing gender relations among the pastoral Maasai. As noted, conflicts around land in Kilosa are long standing and recurrent, frequently associated with access to and use of land and water for livestock and farming, as well as investment. These conflicts take three dominant patterns: pastoralist-farmer conflicts; conflicts between pastoralists and Mikumi National Park; and pastoralist-investor conflicts. Further, the attempt by the state to mitigate conflicts, namely through Operation Kilosa 'OKI' is also considered to exacerbate existing conflict patterns through the violence and disruption inflicted upon pastoral Maasai.

While women do not participate directly as combatants, these conflicts affected women and their children differently from men by virtue of their position as default home managers and caretakers. Conflict induced displacements disrupted their access to resources like water, firewood and herbal medicines [for domestic use and income generation]. Testimonials by women who had experienced displacement revealed the enormous difficulties of losing houses, food stores and cooking equipment. Further, since women and their children are usually left behind and are often unarmed unlike male combatants, they were vulnerable to insecurity, rapes, theft, and loss of income, hunger and increased workload as they attempted to continue to fulfill their roles as home managers and caregivers. The sudden execution of Operation Kilosa in 2009 that led to displacement, abuse, and loss and/or restricted access to land had similar effects on women as the conflicts themselves. These findings corroborate the argument that conflicts have gender-differentiated impacts; women by virtue of certain specific gender roles experience them differently (Mkutu, 2008). In the same way, they also corroborate the observations by Tadesse (2010) in Ethiopia that, due to their status, women are caught in a vicious paradox as firstly, they are victims of conflicts and secondly, they are often powerless to defend or protect themselves.

In Kilosa, the picture is complex, with the strain and hardship associated with gen- 
der differentiated roles and gender relations on the one hand reinforced by conflicts. On the other hand, conflicts or other hardships may be a trigger for change and a challenge to existing gender roles and relations, an argument that corroborates the work of Mkutu (2008) in Karamoja, Uganda, where conflict and other social changes led women to seek alternative livelihoods from which they and their children were able to benefit. However, several other social factors have assisted this transformation process among the pastoral Maasai communities, including exposure to the outside world, and the influence of the Christian church in Kilosa. As noted however, few women as yet have been partakers of this social change. The research concludes by arguing that conflicts around land in Kilosa are partly triggered by the pluralistic and contradictory nature of the land laws, which have accelerated inequalities in access to and control of land to pastoral Maasai. Pastoral women as default home managers and caregivers experience a double blow, confirming the assertion that conflict impacts are gender differentiated, and women are differently affected by these conflicts.

\section{The role of climate change}

The third research question explored is whether climate change is taking place in Kilosa, and its link to the existing land use conflicts, taking a gendered approach to the impacts of this. Available data and interviews suggested that climate has changed over recent decades resulting in prolonged droughts, unpredictable rainfall, floods, and new outbreaks of animal and human disease. The findings corroborate existing scholarly work in Kilosa (Mushi, 2013) and government reports (URT, 2007; 20I2). The government has not been able to mitigate these impacts effectively, especially with reference to recurrent floods in Kilosa. Clearly, policy failures in management of drainage and water systems are an important factor in the problem, which is often blamed solely on climate change, and the latter may be used to justify certain political agendas.

Drought induced migration, (which may be forceful, arranged between communities, or the result of bribery of officials), is linked to land use conflicts. However, despite drought being one of the most serious challenges for pastoralists, the relationship with conflict is not actually consistent. Conflicts have also been evident in the absence of prolonged drought, suggesting that other factors are involved in conflict. As hinted, policies and decisions are part of the problem. Pastoralists are migrating from different parts of Tanzania to Kilosa, while at the same time the government is moving them elsewhere including Rufiji and Ikwiriri districts without consideration of their settlement strategies. Despite attempts by the government to solve or mitigate conflicts, climate induced impacts [degradation, deforestation] are creating other conflicts in Kilosa and elsewhere. Thus some of the laws and decisions that have been created by government to solve conflicts are exacerbating conflicts in Kilosa. The research concludes by challenging the theoretical arguments that there is a direct link between climate change and conflicts arguing that while climate change is taking place in Kilosa, this is not directly linked to the long standing and recurring conflicts around land in the area, rather, climate change is a threat multiplier to existing conflicts around land, environmental induced migrations, and border disputes. 
Findings also show that vulnerabilities to unprecedented impacts of climate change events are gender differentiated. Pastoral Maasai women were found to experience climate change induced impacts differently, mostly due to socially constructed roles and responsibilities they play within their societies, the secondary position they have in resource access, and the skewed gendered power relations which tend to make them more destitute relative to men. In a specific way, as a threat multiplier, climate change is exacerbating the existing unequal resource access and gendered power relations in resource access experienced by pastoral women, consequently limiting their ability to cope with and adapt to a changing climate. In some cases the disproportionately negative impacts endured by pastoral women are not always straightforward due to multiple roles and responsibilities they play (food managers, care givers, guardians and economic actors). Some women have been able to break through customs and migrate to the cities in search for alternative economic niches to manage their roles. Observations by Eriksen et al. (2005), Dankelman et al. (2008) and Omolo (2010) corroborate these findings. Adaptation policies and related development interventions in Kilosa are also hindering pastoral mobility, while a lack of other possible livelihood options is pushing more and more pastoralists out of their pastoral system. Ultimately, it is a woman who suffers because the subsistence of pastoral women is land.

\section{Food security, conflict and pastoral women}

The fourth research question intended to explore the way in which food insecurity, triggered or exacerbated by conflict, impacts pastoralist women's livelihood. The work considered whether there is food insecurity amongst the pastoral Maasai, and if so, what is its relationship with conflicts around land. Lastly the meaning and impact for pastoral women was explored.

As has been described pastoralists have been increasingly forced to change their dietary practices and food preferences from a cattle products oriented diet [milk, meat and blood] to a higher intake of cereals and vegetables. Although the new foods have a recognized nutritional value, according to the Maasai, food means milk, meat, and blood, but not cereals. Thus a kind of food insecurity exists for the Kilosa Maasai because their local food preferences and dietary practices are no longer available. This work argues that cultural food preferences are important because they are intertwined with beliefs about health, livelihoods and sustainable food supply. When change is involuntarily enforced upon a community, it strains those individuals who are by default in charge of food, in this case pastoral women [food managers]. This observation also corroborates the theoretical argument that food insecurity is subjective to preferences as supported by FAO (2006) and Fenton et al (2012). It then becomes important to ask how the government is addressing food insecurity in the country. The conventional wisdom of food security interventions through agricultural expansionism at the expense of pastoralism exacerbates food insecurity specifically among the pastoral Maasai. The government does not see pastoralism as a valuable livelihood system, yet pastoralism contributes considerably

to the Gross Domestic Product (URT, 2006; Kipuri and Sorensen, 2009). The inevitable result is food insecurity, which impacts particularly on women and children. Ultimately, 
women are impacted heavily by virtue of their specific and default gender roles [food managers and caregivers]; they are confronted with insecure rights to property like land, as well as a lack of power in land and livestock matters.

\section{Conclusion}

Generally, this research concludes that land use conflicts and the livelihood of pastoral Maasai women in Kilosa are complexly linked and multifactorial. Vulnerabilities to these conflicts around land are gender differentiated, and pastoral Maasai women experience climate change, food insecurity, and land reforms differently from men. In as far as land reforms and pastoral Maasai women are concerned, customary practices, structures and institutions that mediate access to and use of land, work to their disadvantage. Thus, for secure land reforms, the structures - political, economic, and social - through which land access is mediated, must also be reformed. Likewise, in the context of conflicts this research concludes that land use conflicts have a disproportionate gendered effect, and women are the most hit hard in conflict situations. Equally, climate change is one of several factors that aggravate conflict, and ultimately exacerbate the plight of women. Likewise, food insecurity and conflict are intricately linked, and women as default food managers shoulder the heaviest burden.

\section{Theoretical implications of the research}

This research depicted a number of findings that have implications to the existing theoretical debates regarding land conflicts and the livelihood of pastoral Maasai women. First, the research challenges the theoretical perspective that individualized land rights are more effective and desirable in promoting tenure security, wider equal opportunities and efficient use of land, and suggests rather that communal land rights are the most effective way to ensure tenure security and promote gender equality in land and land resource access. The research highlights that, despite Tanzania having seemingly good laws that are pro-gender equality as it relates to land access and use, these fail to benefit this particular sub-group of women, and rather, erode the only access to land that they enjoy.

Similarly, this research contrasts the theoretical argument which claims a direct causal relationship between climate change and conflicts. It reveals that there is no direct link between change in climate and conflicts around land in Kilosa, implying that this claim is inappropriate and misleading, and detracts from other important factors. The concept of climate change as a threat multiplier to conflicts is preferred in this work. A significant factor in the problem is seen to be policy and resource governance; concurring with the theoretical argument that climate change is a political issue. This research equally confirms the theoretical argument that, unlike men, women often bear the brunt of burden of climate change related conflicts due to different gender roles and unequal distribution amongst them.

While this study confirms the theoretical positions that conflicts instigate food insecurity by affecting local food systems, while on the other hand, food crises intensify food 
competition and create conflicts, it is established in this research that land conflicts and food insecurity in Kilosa are complex and multifaceted issues, involving issues of climate and institutions, particularly the nature of the state-society relationships as reflected in policy actions such as eviction and land alienation. Ultimately, these circumstances impact heavily on women by virtue of their specific and default gender roles [food managers and caregivers]. This confirms the theoretical arguments that, unlike men, women as food managers are highly affected by food insecurity induced conflict.

\section{Land conflicts and the livelihood of Pastoral Maasai Women in Tanzania: the way forward}

In view of the above, understanding conflicts around land in relation to land reforms, climate change, food insecurity, and gender in Kilosa is a complex issue that cannot be analyzed from one factor or perspective alone. Analysis of these conflicts requires a holistic approach and strategies that understand the intricate nature of the conflicts, and how policy and governance related factors contribute and exacerbate the plight of the pastoral Maasai women in Kilosa as already demonstrated. This study is an original contribution to the micro-level analysis of conflicts around land in relation to land reforms, climate change, food (in)security and livelihood of pastoral Maasai women in Tanzania.

Specifically, in the context of the increasing pressures on land and its related resources in Tanzania for instance, land grabbing and the land rush due to global food insecurity and changing climate, the entire issue of pastoralism, conflict, gender and policy needs to be reconsidered in full. The pastoral livelihood has always been exposed to the vagaries of climate and harsh environmental conditions. However, in recent years, pastoralists have faced a myriad of new problems, including competition for water and pasture in the context of decreased access to land; more explicit political and economic marginalization; a lack of appropriate responses to the deteriorating security situation; and the proliferation of weapons across the region. The current policies are not attempting to handle pastoralism but appear to consider it a worthless livelihood to be discouraged; neither are they sympathetic to the plight of the women and their children. If Tanzania is to meet goal no. 3 of the Millennium Development Goals by 2015, which aim at promoting gender equality and empowerment of women (United Nations, 20I4), it will also have to think of what is happening among the pastoralist women and their children.

As far as land reform is concerned, a very well developed gender sensitive land institutional framework exists, and women's rights to land are statutorily protected. However, this work questions this sensitivity in the sense that, to date, customary practices still block women in pastoral areas to enjoy these rights. What reforms overlook is that women in pastoral areas are the property of men, and a property cannot own property. In this regard, there is a need to rethink pastoral women's rights in the context of land and land reforms. Likewise, whereas land reforms have opened up room for market forces in land and large scale farming, policy frameworks like Kilimo Kwanza do not consider pastoralists, but rather promote land grabbing in pastoral areas. There is a need to rethink the issue of pastoralism because even the Kilimo Kwanza policy is insensitive to 
this group and accelerates grabbing of even the marginal lands, on which pastoralists subsist. Modernization policies in agriculture should not only focus on crop farming, but also take into account modernizing pastoral farming. For instance, just as the Kilimo Kwanza policy emphasizes a green revolution through agriculture, similar attention should be given to assisting pastoralism to continue as a sustainable livelihood, with adequate production of livestock and livestock products [milk, meat, ghee etc.] to sustain women's livelihood as home managers and to reduce unregulated pastoralist movements, which fuels pastoral-farmer land conflicts.

Similarly, in as far as climate change is concerned, the government is attempting to sedentarise pastoralists, failing to recognize the value of pastoralism as a livelihood and that some areas are only suitable for pastoralism. Thus pastoralism is receiving insufficient analytical debate at the policy level. The need for such a debate is made more pressing by the recent mineral finds in pastoral areas, which have led to conflict, evictions and deaths of pastoralists as in Ngorongoro and Kilombero (Laine et al., 2013). When evictions take place this is poorly planned and leads to land conflict in other areas, as was the case in the Rufiji pastoral-farmers conflicts. As noted, during Operation Kilosa (OKI), the eviction of Maasai pastoralists from Kilosa to the Lindi and Rufiji regions leading to conflict with Sukuma pastoralists was a policy failure. Further, with regard to food insecurity, the work has demonstrated that pastoralists in Kilosa are food insecure, and a complex link exists between food insecurity and land use conflicts, in which climate and institutional factors play a role. This challenges the conventional wisdom of food security interventions, which fail to consider pastoralism. The introduction of forage crops production may assist to boost food production among the pastoralists at the same time reducing herd mobility. The case of Vikuge state farm, located in Vikuge village, Soga ward in the Kibaha district, northwest of Dares Salaam, is an example (Kevane et al., 2005). This farm focuses on the production of grasses and legumes; this could be replicated to support pastoralists in Kilosa and elsewhere.

\section{Suggestions for Further Research Projects}

While this ethnographic inspired research aimed at exploring conflicts around land and how they impact on the livelihood position of the pastoral women in Kilosa, it must be acknowledged that the results presented cannot cover all the conflict dynamics around land in Kilosa. There remain many unexplored aspects of the complex relationship between land conflicts, pastoralism and gender. With regard to longstanding and recurring conflicts around land in Kilosa, there is a need to look further into the ways to mitigate these conflicts without exacerbating livelihood insecurity further, such as has happened on numerous occasions, when pastoralists are evicted as a means of resolving land conflict (Mkomazi, Ihefu, Kilombero to name a few cases). The matter of compensation is an important concern for past, present and future cases. One of the most important challenges for future research is the climate change phenomenon. As findings indicate, scholars and policy makers have predicted an increase in drought and flooding in various parts of Tanzania, including Kilosa. The need for further research and action to mitigate 
the impact on pastoralists, and pastoral women in particular, cannot be underestimated. There is a need for inclusion of Maasai pastoralists in decisions affecting their future. Furthermore, pastoralists are food insecure, and a complex set of factors contributes to this state, such as unpredictable rainfall, institutional factors, and conflicts around land. Women, by virtue of their default gender roles and responsibilities and users of climate sensitive resources in skewed power relations bear the brunt of the impacts.

A question that remains and needs to be looked into further is how these women are going to survive in a changing climate with dwindling resources under continuous population growth and policies that favour agricultural expansionism at the expense of pastoralism. Given the food insecurity situation among the pastoral Maasai, it may be worse for women, who are the social-economic engines of the pastoral livelihoods (Eneyew and Mengistu, 2013). If the women cannot have their cultural diet during pregnancy or after delivery, their life expectancy and ability to perform their gender specific roles are likely to be affected. Thus, future research may assess the vulnerability of the pastoral women by conducting a comprehensive understanding of the complex interactions between climate, demographic factors, livestock and human disease and political and economic systems.

\section{References}

Asheber, S.A. (2010). Mitigating drought: Policy impact evaluation: A case of Tigray region, Ethiopia. Enschede: University of Twente, Faculty of Geo-Information and Earth Observation. ITC.

Barnett, J., and Adger, N. (2007). Climate Change, Human Security, and Violent Conflict. Political Geography, 26 (6), 639-655.

Benjaminsen, T.A., Maganga, F. P., and Abdallah, J. M. (2009). The Kilosa Killings: Political Ecology of a Farmer-Herder Conflict in Tanzania. Development and Change, 40 (3), 423-445.

Butler, J. (I990) Gender Trouble. New York: Routledge

Dankelman, I., Alam, K., Ahmed, W.B., Gueye, Y.D., Fatema, N., and Mensah-Kutin, R. (2008). Gender, climate change and human security: Lessons from Bangladesh, Ghana and Senegal. WEDO.ABANTU.ENDA.

De Soto, H. (2000). The mystery of capital: Why capitalism triumphs in the West and fails everywhere else. New York: Basic Books.

Deere, C.D., and Leon, M. (2003). 'The Gender Asset Gap: Land in Latin America', World Development 3I(6): 925-47.

Diamod, J. (2005). Malthus in Africa: Rwanda's Genocide. In J. Diamond, Collapse: How societies Choose to Fail or Succeed. London: Penguin Books Ltd.

Eneyew, A., and Mengistu, S. (2013). Double Marginalized Livelihoods: Invisible Gender Inequality in Pastoral societies. Societies, 3, I04-II6.

Eriksen, S. and Lind, J. (2005). The impacts of conflict on household vulnerability to climate stress: Evidence from Turkana and Kitui Districts in Kenya. Human Security and Climate Change, An International Workshop, Holmen Fjord Hotel, Asker, near Oslo, 2I-23 June 2005.

FAO (2006). Food Security. Rome: Food and Agriculture Organization.

Fenton, C., Hatfield, J. and McIntyre, L. (2012). A qualitative pilot study of food insecurity among Maasai women in Tanzania. PanAfrican Medical Journal, I2.

Flintan, F. (2008). Women Empowerment in Pastoral societies. WISP; Global Environment Facility; UNDP; IUCN. 
(20II). The Political Economoy of Land reform in Pastoral Areas: Lessons from Africa, Implications for Ethiopia. Future Agricultures, IDS University of Sussex; Feinstein International Center of Turfs University

Fratkin, E. and Roth, E. (2005). The Setting. In Fratkin, E., Roth, E., and Nathan, M. (Eds.): As Pastoralists Settle, pp. 29-52. New York (NY, USA): Kluwer Academic/Plenum Publisher.

Hoste, J.C. and Vlassenroot, K. (2009). Climate Change and Conflict in Sub-Saharan Africa: the Mother of all Problems? International Symposium. Developing Countries facing Global Warming: a PostKyoto Assessment (pp. I39-I49.). Brussels: Royal Academy for Overseas Sciences. United Nations.

Hughes, S. and Hughes, B. (200I). Women in Ancient Civilizations. In A. Michael, Agricultural and pastoral Societies in Ancient and Classical History (pp Ir6-I50): Philadelphia: Temple University Press.

Joekes, S. and Pointing, J. (I99I): "Women in Pastoral Societies in East and West Africa” Dry Lands Network Programme Issue Paper No. 28. International Institute for Environment and Development (IIED), London, UK.

Karl, M. (2009). Inseparable: The Crucial Role of Women in Food Security Revisited. Women in Action, I, I-I9.

Kevane, M. and Gray, L. (2008). Darfur: Rainfall and Conflict. New York, USA: SSRN.

King, N. (2013). Conflict Management among the Farmers and Pastoralists in Tanzania. International SAMANM Journal of Business and Social Sciences, I (2), 40-50.

Kipuri, N. and Ridgewell, A. (2008). A Double Bind: The Exclusion of Pastoralist Women in the East and Horn of Africa. UK: Minority Rights Group International.

Kipuri, N. and Sфrensen, C. (2009). Poverty, pastoralism and policy in Ngorongoro: Lessons learned from the Ereto I Ngorongoro Pastoralist Project with implications for pastoral development and the policy debate. ERETO/ IIED.

Levine, S., Peters, K., and Fan, L. (20I4) Conflict, Climate Change and Politics: Why a Techno-Centric Approach Fails the Resilience Challenge. HPG Working Paper. London, UK: ODI.

Maganga, F., Odgaard, R. and Sjaastad, E. (2007). Contested Identities and Resource Conflicts in Morogoro Region, Tanzania: Who is Indigenous? In B. Derman, R. Odgaard, and E. Sjaastad, Conflicts over land and Water in Africa (pp. 203-2I4). Oxford.East Lansing. Pietermaritzburg: James Currey. Michigan State University Press. University of Kwazulu-Natal Press.

Meier, P., Bond, D., and Bond, J. (2007). Environmental influences on pastoral conflict in the Horn of Africa. Political Geography, 26, 716-735.

Messer, E. and Cohen, M. (2006). Conflict, Food Insecurity, and Globalization. Washington, DC: International Food Policy Research Institute.

Misafi, H. (20r4). Women's Participation in Decentralized Local Governance: The case of Pastoral and Non-Pastoral Women in Kondoa Authority,Tanzania. Afrika Focus, Vol. 27 (2), $87-97$.

Misselhorn, A.A. (2005). What Drives Food insecurityin Southern Africa? A Meta-analysis of Household Economy Studies. Global Environmental Change I5, I5, 33-43.

Mkutu, K. (2008). Uganda: Pastoral Conflict and Gender. Review of African Political Economy, 35 (II6), 237-254.

Moon, B.K. (2007). June I6). A climate culprit in Darfur. Washington Post, p. Ar5.

Morrissey, J. (2009). Environmental change and forced migration. Workshop on Environmental change and forced Migration: A State of the Art Review, Refugee Studies Centre, Oxford Department of International Development, Queen Elizabeth House, University of Oxford, Oxford.

Mushi, V. (2013). Women Pastoralists and Climate Change Impacts in Kilosa District, Tanzania. In M. Mulinge, M. Getu, M. Mulinge, and M. Getu (Eds.), Impacts of Climate Variability and Change on Pastoralist Women in Sub-Saharan Africa (pp. I55-185). Addis Ababa. Kampala: OSSREA. Fountain Publishers.

Nelson, G. (2008). Review of the Gender Dimensions of Land-Based Conflict in the Pacific. Land Management and Conflict Minimisation Sub-Project 2.6. Suva. Suva.Fiji: The Pacific Islands Forum Secretariat LMCM project. 
Obeng-Odoom, F. (2012). Land reforms in Africa: Theory, practice, and outcome. Habitat International $36, \mathrm{I} 6 \mathrm{I}-\mathrm{I} 70$.

Pedersen, R. and Haule, S. (2013). Women, Donors, and Land Administration: The Tanzania Case. In DIIS Working Paper 2013:19. Copenhagen, Denmark: DIIS.

Redding-Jones, J. (2005). What is Research: Methodological Practices and New Approaches. Oslo: Universitetsforlaget.

Shao, I. (2008). Democracy and Land Conflicts in Tanzania:The case of pastoralists versus Farmers. Tanzania Journal of Development Studies, 8 (2), $7 \mathrm{I}-83$.

Simmons, E. (2013). Harvesting Peace: Food Security, Conflict, and Cooperation. Washington DC: Woodrow Wilson Center for Scholars.

Tadesse, B. Tesfaye, Y. and Beyene, F. (2010). Women in conflict and indigenous conflict resolution among the Issa and Gurgura clans of Somali in Eastern Ethiopia. African Journal on Conflict Resolution, Io (I), 85-110.

United Nations (2014). Millenium Development Goals Report. NewYork: United Nations.

\section{United Republic of Tanzania (2006). National Livestock Policy. Ministry of Livestock Development. Dares Salaam: Tanzania Government Printers.}

(2007). National Adaptation Programme of Action. Vice President's Office, Division of Environment. Dares Salaam: URT.UNEP.GEF.

_ (2010). Kilosa District: Socio- Economic Profile. Kilosa, Tanzania/Morogoro: Tanzania Government Printers.

__ (2012). National Climate Change Strategy. Dares Salaam: Vice President's Office. Division of Environment.

Young, L. and Sing'Oei, K. (20II). Land, Livelihoods and Identities: Inter-Community Conflict in East Africa. London: Minority Rights Group International. 